\title{
Two swallow species from the early Pliocene of Langebaanweg (South Africa)
}

\author{
Albrecht Manegold \\ Acta Palaeontologica Polonica 55 (4), 2010: 765-768 doi: http://dx.doi.org/10.4202/app.2009.0153
}

The Varswater Formation of Langebaanweg at the west coast of South Africa is one of the few fossil sites in Africa

dating from the early Pliocene (approx. 5 Mya) (Hendey 1981) and excels in being especially rich in well preserved,

though generally isolated, bird remains. Rich (1980: 166) regarded this site as richest pre-Pleistocene bird bone accumulation in the world with at least 60 bird species representing among them penguins, tubenoses, parrots and mousebirds. Studies on seabirds, ibises and other taxa (Olson 1985a, b, 1994) indicated that the Pliocene avifauna is even more diverse than initially thought. Passerines are represented by at least nine species (Rich 1980), but no attempts have been made so far to identify these specimens below the subordinal level. The screening of previously unsorted and unidentified material excavated during the 1960s and 1970s at "E" Quarry, Langebaanweg, yielded several hundred remains of passerines. This sample included five fragmentary humeri that show the characteristics of swallows and martins (Hirundinidae), which are described herein.

Albrecht Manegold [albrecht.manegold@senckenberg.de], Forschungsinstitut Senckenberg, Sektion Ornithologie, Senckenberganlage 25, D-60325 Frankfurt am Main, Germany.

This is an open-access article distributed under the terms of the Creative Commons Attribution License (for details please see creativecommons.org), which permits unrestricted use, distribution, and reproduction in any medium, provided the original author and source are credited. 
